\title{
DIGESTION OF THE CESOPHAGUS AS A CAUSE OF POST-OPERATIVE AND OTHER FORMS OF HAMATEMESIS.*
}

\author{
By J. Hogarth Pringle, Laurence T. Stewart, and \\ JOHN H. TEACHER.
}

From the Royal Infirmary, Glasgow.

\section{(Plates XXII.-XXV.)}

MosT of the material which forms the subject of this communication was also the subject of an article by Mr Pringle and Dr Teacher in the British Journal of Surgery, 1919, vol. vi., No. 24, p. 523. Details are there given of the clinical history and post-mortem appearances in fifteen cases in which digestion of the oesophagus was supposed to have occurred during life. The subject was treated from the clinical and morbid anatomical standpoints only because during the war it was found impossible to make adequate histological examination. Fortunately most of the osophaguses had been preserved, and we have now made histological examinations of fifteen out of eighteen specimens. All except one of these showed signs of vital reaction, and that which gave a negative result is of particular interest, the disease being clearly of vital origin.

Post-mortem digestion of the cesophagus and digestion of the csophagus occurring during life or " essophago-malacia" or "ulcus a digestione" are described in the text-books of pathology. The most complete account of the subject with which we are acquainted is given in Kaufmann's Specielle Pathologische Anatomie, where cases are referred to which are clearly of the same nature as those with which we now deal. All degrees of post-mortem digestion occur, and slight degrees of it are stated to be common, a statement which we can confirm. Digestion during life is stated to be extremely rare, and the connection between it and the vomiting of black material or actual hæmatemesis following operation is not mentioned. We have not followed up his references to literature. In view of our experience, the rarity of digestion of the cesophagus during life is open to question, as we have observed at post-mortem examination sixteen cases of it in the last seven years (Jan. 1914 to Jan. 1921). In our opinion, some at any

* Received May 25, 1921. 
rate of the cases at present regarded as post-mortem digestion will require to be transferred to the category of actual and important disease.

In considering the subject of post-operative hæmatemesis one must exclude those cases in which the symptom follows upon some direct surgical interference with the stomach itself, and also those cases of patients who suffer from a gastric or duodenal ulcer at the time of undergoing an operation for some altogether different disease. Apart from these cases, post-operative hæmatemesis is a symptom of great importance to the practical surgeon and associated with serious danger to the patient. Fortunately it is not of frequent occurrence, for many patients who develop this symptom die, and those who recover do so after very critical illness. In recorded cases, various explanations are given, but digestion of the osophagus is not mentioned.

Hæmatemesis due to digestion of the cesophagus is also found in cases of injury and in patients suffering from non-surgical diseases (e.g., eclampsia and anthrax). The nature of the illnesses is very varied, but in all of them there is extreme exhaustion and depression of vitality. (See table below.) In some cases the cesophageal condition may not be the cause of death, and we have obtained clear evidence that healing may occur in such cases; but there can be little doubt that the extensive ulceration of the csophagus and hrmorrhage constitute a serious complication, while the perforation into the pleural cavities in the extreme cases would certainly be fatal. In some cases it appears clinically to have been the actual cause of death. In our previous communication we underestimated the severity of the injury to the œsophagus. Microscopic investigations show it to be far more profound than we had imagined from the naked-eye appearances, and most of the cases described as slight or early are hardly entitled to be so described.

\begin{tabular}{|c|c|c|c|c|}
\hline \multicolumn{5}{|l|}{ a. . } \\
\hline \multicolumn{5}{|l|}{ Surgical Cases :- } \\
\hline Appendicitis & & . & . & \\
\hline \multicolumn{2}{|c|}{ Pancreatitis and gallstones } & . & . & 310 \\
\hline Duodenal ulcer . & . $\quad$. & . & . & \\
\hline \multicolumn{5}{|l|}{ Accidents:- } \\
\hline Rupture of liver & . & . & . & $1\}_{2}$ \\
\hline Fracture of femur. & . & . & . & $1 \int^{2}$ \\
\hline \multicolumn{5}{|l|}{ Medical Cases :- } \\
\hline Anthrax & 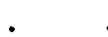 & . & . & 1) \\
\hline Obscure (? Hepatitis & & . & . & \\
\hline Puerperal eclampsia & & . & . & 2 \\
\hline Pneumonia. . & 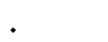 & . & . & 2) \\
\hline
\end{tabular}

Signs and Symptoms.

The principal sign of digestion of the eesophagus is vomiting of black or brown material. In some eases there is vomiting of red blood. The amount vomited at any one time is nsually small. Hæmatemesis 
or vomiting of black or brown material was recorded in thirteen out of the eighteen cases which we have seen. In the remaining five cases $i t$ is possible that this did not occur as they were of a very acute severe type, all but one with perforation into the pleural cavities; four of them were under observation in hospital.

In some cases of hæmatemesis (two of the present series) pain behind the sternum or between the shoulders has been recorded and is probably a characteristic symptom; but is doubtless in some cases masked by pain due to the principal disease and in others by the extreme illness of the patient. In this connection the severe pain which is experienced in inflammation of the csophagus may be referred to,- - every portion of food sivallowed feels like a body about the size of a walnut passing down the chest and the pain ceases abruptly when the bolus has passed the cardiac orifice.

Digestion of the œsophagus during life is supposed by us to arise in the following manner. Vomiting of active gastric juice occurs, but the cesophagus fails to clear itself and some of the fluid remains accumulating particularly in the lower third of the tube where the injury is always most severe. In nine of our cases fairly exact time data are available and in seven of these the period between the occurrence of hæmatemesis and death was from twenty to thirty-eight hours. In one case it was forty-three hours and vomiting had ceased before death and there are microscopical appearances in the sections from this case which are suggestive of commencing recovery (not figured). The condition, therefore, is not an agonal one.

In post-operative hæmatemesis the fluid ejected is usually extremely acid, and those patients who are sufficiently conscious to be able to express themselves frequently complain of the scalding effect which it has upon the throat and lips. This indicates an active fluid, and, as will be seen from the description of the lesions, the process of digestion is often very acute and destructive. The appearance of the lower part of the cosophagus in such cases is fairly comparable with what is seen in extreme cases of digestion of the stomach, the tissues being swollen and pulpy and broken down.

Two very striking and distinctive phenomena have, however, to be noted:-(1) The presence of black sloughs indicative of intense congestion and hæmorrhage, and (2) the contrast between the broken down cesophagus and the stomach, which is either totally free from digestion or is relatively slightly digested. These points will be further referred to after the lesions have been described.

\section{Structure of the Esophagus.}

The mucous membrane of the cesophagus consists of a thin, fibrous layer, fairly vascular but with rather scanty cell elements except where patches of lymphoid tissue occur, which is covered by a fairly thick layer of stratified squamous epithelium (Plate XXIV., Figs. 12 and 13). 
Beneath the thin, fibrous membrane is a relatively thick muscularis mucose, and between that and the strong inner circular muscular coat is a layer of loose fibrous tissue in which the larger blood-vessels are found. There are a fair number of mucous glands which may extend through the whole thickness of the mucosa and sub-mucous connective tissue. Leucocytes are very few in number in the normal mucosa. The outer muscular layer runs longitudinally. There is not much fibrous tissue among the muscle. Outside there is much loose areolar tissue. At the lower end the transition from the csophageal to the gastric mucous membrane is fairly sharp but variable in its sharpness and in the exact level at which it occurs.

\section{Post-mortem Changes in the CEsophagus.}

It is very common to find a certain amount of digestion of the œsophagus in association with post-mortem digestion of the stomach. It is shown by relaxation of the tube and softening of its inner surface. The colour is dull grey with some diffuse darker coloration. The epithelium may be unrecognisable, or shreds of it may be found free or adhering loosely to the underlying tissue (Plate XXIV., Figs. 12 and 13). The underlying tissues may be broken down but usually they are not dissolved beyond the muscularis mucosw. Microseopically the nuclear staining is lost (Plate XXIV., Fig. 14) and the cell bodies and fibres tend to be swollen so that the tissue seems denser and more homogeneous than the normal. Later the tissues become opened out in the process of breaking down. The submucous areolar tissue may appear slightly codematous. In all the tissues there is an absence of reaction. The blood corpuscles in the vessels are broken down or reduced to shadows, and the hæmoglobin may have caused some staining of the surrounding tissue. Destruction of the cesophageal tissues may occur just as the stomach may be digested to the point of rupturing; but we have seen this much less frequently than we have seen the intra vitam digestion of the cesophagus and we feel that these cases are more likely to be of ante-mortem type.

Histologically as well as to the naked eye, the great point of contrast is that in the cases now reported the cesophagus is digested while the stomach is not at all or only slightly affected. It is possible that a good deal of what is regarded as post-mortem digestion of the surface of the cesophagus is really the result of the activities of bacilli, myriads of which we commonly find on the surface and in the tissues of our sections--a putrefactive rather than a strictly digestive effect.

In whatever manner these changes, which are histologically those of acute necrosis, are produced, they are apt to render indistinct or even to obliterate the evidences of vital reaction. This largely accounts for our failure to recognise the vital changes in the few sections which were cut during the war. 


\section{Intra-vitam Digestion of the CEsophagus.}

The appearances found on post-mortem examination in cases of digestion of the cesophagus during life present considerable variation, and the microscopic changes, which are in general of the nature of acute injury and acute inflammatory reaction, also vary greatly. Classification is therefore difficult, but division of the cases into three types will probably be found practically useful.

Type I.-Slight-two cases. Nos. 12 and 14.

Type II.-A severe and extensive nlceration of the cesophagus without perforation - seven cases. In our paper of 1919 most of these are described as slight, but microscopic examination shows far more damage than was imagined from the naked-eye examination.

Type IIr.-Cases with perforation or widespread destruction of the lower part of the cesophagus-nine cases.

Most of the cases from which the time data were obtained belong to Type II., but from comparison of the histological pictures we are of the opinion that most of the perforative and destructive cases are of similar duration, namely twenty-four to thirty-six hours. In all probability, however, the course of the disease can be much shorter. For example, in the only case which microscopically showed total absence of reaction, there appears to have been sudden and rapid collapse. (See p. 409.)

\section{Morbid Anatomy of the Different Types.}

Type I.-In these two cases the cesophagus was in a state of relaxation in the lower 4 ins. or thereby and contained a quantity of black fluid. There appeared to be superficial erosion of the mucous membrane in the above area. Hæmorrhages were not a striking feature, and the condition might have been dismissed as post-mortem digestion but for the fact that there was in both cases a history of the vomiting of black material.

Type II.-The seven cases in this group showed two types, of which one is illustrated (Plate XXV., Fig. 15). Two specimens almost identical in appearance have been seen. Externally the lower 4 ins. or thereby of the oesophagus was seen to be extremely congested and the muscular tube stripped very cleanly from the surrounding connective tissues. Higher up the appearance became normal. Internally, the mucous membrane was deeply congested and there were long streaks of dark brown colour which looked like the result of hæmorrhage into the mucous coat. This condition extended from the cardiac orifice upwards for about 4 ins., the brown streaks gradually tailing off into a light brown discoloration suggestive of superficial necrosis. The upper part of the cesophagus appeared fairly normal. The œsophagus was in the contracted condition and the brown streaks covered the crests of the rugæ, the furrows between being of lighter colour and apparently less damaged. This was well marked only in the upper and less 
affected parts. Microscopic examination revealed more damage than was expected (Plate XXII., Figs. 3 and 4). There was a slight line of ulceration close above the cardiac ring.

In the other three cases the cesophagus was relaxed and contained much black fluid. The surrounding areolar tissues were softened and blackened or infiltrated with blood, and the tube was mottled with black. Internally the condition either resembled Fig. 443, p. 527, in our communication of 1919 , the surface being light coloured with streaks of hæmorrhage or showed the mucous membrane to be mostly covered with black sloughs. In several cases the tube bulged in places as if on the point of perforation. An important feature was the presence of a well-marked zone of irregular somewhat ragged ulceration immediately above the cardiac ring. This feature of the specimens is specially referred to by Kaufmann (loc. cit.) and helps to identify our cases with those which he describes. The difference in the general colour appears to depend upon whether the killed layers of the mucosa had been digested away or not. Most of the inner surface of the affected area is smooth, and the cause of this was found to be that the ulceration generally had not extended beyond the muscularis mucosæ. In the ragged zone and in the bulges, as in the more severe lesions of Type III., that structure, which is probably fairly resistent, has been broken down and digested away.

Type III.--In this type perforation having occurred into one or both pleural cavities, the first indication which is obtained is due to finding black fluid in the pleural cavity when examining the lungs before removal of the thoracic viscera. The œsophagus is found to be collapsed and surrounded by soft black material, or in extremo cases it may be reduced to a bundle of shreds or altogether destroyed from the diaphragm to the bifurcation of the trachea. Internally the appearances of the lower third suggest advanced digestion, while higher up the condition tends to resemble one or other form of Type II., and microscopically also shows similar conditions. In two cases the internal surface was covered with black sloughs, but in other cases these had largely been digested away.

In spite of the extreme damage to the csophagus the cardiac ring in nearly all cases (16 out of 18) had remained tight, there being no blood or black fluid in the stomach in ten cases, and but little discoloration of the gastric contents in other six. In two cases the destruction had invaded the cardiac ring and the gastric contents were escaping into the ploural cavities.

The stomach was regarded, on naked-eye examination only, as showing no post-mortem digestion in ten cases, slight in six, considerable in one, and well-marked in one case. On more critical investigation it was recognised that there was frequently a considerable degree of postmortem digestion in the usual dependent position, but not at the cardiac orifice. Microscopic examination of the cardiac region in JOURN, OF PATH, 一VOL. XXIV. 
twelve cases revealed unusually good preservation of the stomach in five cases, slight digestion in four cases, and considerable in three cases; but even in the worst, it was slight compared with the condition in the cesophagus.

The condition of the lungs has been investigated but little as few specimens had been kept. Only in one (Case IV., Fig. 444, in Journal of Surgery, loc. cit.) was there fibrinous exudate on the pleural surface and inflammatory reaction in the superficial alveoli. In several cases digestion of the surface was marked, and there was hæmorrhage into the alveoli and early pneumonia, but the pneumonia appeared to be part of a hypostatic pneumonia.

In the less advanced perforation cases, where little fluid had escaped, and in some which had not perforated, the surfaces of the lung adjacent to the osophagus showed intense congestion and small hæmorrhages under the pleura. These are clearly vital phenomena. In more advanced cases the pleural sacs contain a varying quantity of black or slate-coloured fluid, and large areas of the surface of the lungs show digestion, being black and softened and having a woolly appearance. About the margin of the digestion there are frequently bells of gas in the surface of the lung and small hæmorrhages.

\section{Microscopic Appearances.}

The microseopic appearances vary very greatly according to (1) the degree of damage or destruction inflicted on the tissues by the gastric juice; (2) the amount of reaction which has resulted; and (3) the amount of digestion which has occurred either as a repetition of the lesion or post-mortem.

Details of these changes will be given in the description of the sections connected with the cases which are detailed below. An attempt is here made to give a general description of the main features of the process. It may be fairly said that apart from variation in detail the features of the slight cases are reproduced in the upper parts of the severe cases. Only through this was it recognised that the extremely destructive digestions were actually of intra-vitam origin.

In Type III., but not in the most ad vanced variety, a section throngh the lower part of the csophagus and adjacent part of the stomach shows the condition figured in Plate XXII., Fig. 1. The gastric mucous membrane shows evidence of digestion of the post-mortem type, but is in situ and more or less well preserved. The gastric mucosa ends abruptly in a deep ulceration which begins about the level of the upper surface of the diaphragm. This has destroyed and removed the mucosa and muscularis mucose and has invaded the submucosa. The bloodvessels of this layer are seen dilated and filled with red thrombus. In Plate XXII., Fig. 2, a vein is seen in the depths of black sloughing mucous membrane with its deep side normal, while its superficial side is swollen and in a state of coagulation necrosis and infiltrated with poly- 
morphonuclear leucocytes. The corpuscles in the thrombi are usually mucb broken down, and the pigment is seattered in brown granules through the neighbouring tissues. The muscular layer shows loss of nuclear staining to a varying depth.

In still more advanced cases the whole wall of the tube may be reduced to ragged necrotic shreds. In this part of the specimen it may be impossible to find signs of reaction, the violence of the damage probably having prevented it from accurring. Exceptionally, traces of it have been seen in the outer coat. On looking at the less digested parts of the section, however, in most cases there would be found at the points where vessels pass through the circular muscle a collection of leucocytes which is undoubtedly evidence of reaction. In sections from the higher parts of the cesophagus the acute ulceration as in the other types would be found.

In sections from the specimen figured in Plate XXV., Fig. 15 (Case 17, Post-mortem 9971), the epithelium was found to have been completely destroyed throughout the area of hæmorrhages. Nearly the whole thickness of the mucous membrane persists, but the normal structure is hidden by intense infiltration with polymorphonuclear leucocytes and degeneration, or actual necrosis of the normal elements. The lymphoid tissue seems to be fairly resistant, and can be recognised although over-run with polymorphonuclear leucocytes. In the figures from this case (Plate XXII., Figs. 3 and 4) much of the apparently deeply-stained tissue is not nuclear in nature but is really brown pigment; the blood as a general rule is not recognisable as such in the hæmorrhages, owing to the corpuscles having broken down and the hæmoglobin having taken granular form. The muscularis mucosæ also is in a condition of coagulation necrosis, and, being over-run with leucocytes, is hardly recognisable. The submucous areolar coat is thickened and swollen, and has a peculiar glassy look as if the fibres were swollen and the interstices of the connective tissue full of albuminous coagulum. In slighter degrees of the lesion the condition is clearly one of inflammatory œdema (see Plate XXIII., Figs. 5, 6, and 7).

In the slighter cases and towards the upper margin of the digested area in severe cases the damage becomes more superficial. The epithelium is shed and the surface of the mucosa is in a state of acute ulceration (Plate XXIII., Figs, 6 and 7). Leucocytes are present in great numbers in the mucosa, in the muscularis mucosæ, and in the swollen submucosa. Finally, the section may enter tissues in which there is little alteration from the normal; the epithelium persists and may show signs of reaction in the form of mitotic figures (Plate XXIV., Figs. 10 and 11). A few leucocytes may be found in the underlying tissues and little breaches in the mucous membrane having the character of ulcers may be found (Plate XXIII., Fig. 8). Indications of commencing proliferation of the connective tissue elements are commonly seen, 
and we have specimens from three cases in which these are well developed.

In July 1914, E. E. Glynn gave to the Pathological Society of Great Britain and Ireland a demonstration of ulcerations of the œsophagus. Unfortunately, owing to the war no further publication was made, but the photomicrographs and sections show conditions similar to those described above. Glynn's cases may have been similar to ours in origin, but we have seen similar changes in cases of ulceration which were apparently of different origin.

The changes in the other coats of the cesophagus in our cases are of less interest. As a rule there is some congestion and the vessels may contain an excess of leucocytes and slight emigration may have taken place. In the sections of the cesophagus figured in Plate XXV. near the cardiac end the reaction in the external connective tissue was very acute, there being formation of fibrin in patches with much emigration of leucocytes, and the adjacent lymph glands showed early acute reaction. In the sections from the specimen described on p. 407, Type III., where there was acute fibrinous pleurisy, there were many leucocytes entangled in the partly digested outer coat of the œsophagus.

In many of the specimens there were great numbers of large bacilli, mostly gram-positive, on the surface or actually in the substance of the mucous membrane and deeper still in the advanced cases. These were probably putrefactive. In many sections there was some loss of nuclear staining in the superficial tissues. From the fact that this degenerative change involved the inflammatory exudate, it was concluded that it was of post-mortem origin and due to renewed digestion or to the action of the bacteria (Plate XXIV., Fig. 14). In some cases it was not present and the fixation of the tissues and blood was exceedingly good.

\section{Cases related to the Plates.}

TYPE II.-Less Advanced Variety.

Case 17 (Plate XXV., and Plate XXII., Figs. 3 and 4). Appendicitis, gangrene, suppuration. Drainage and packing. Vomiting of dark-brown material twenty-four hours ante-mortem. Digestion of cesophagus of fairly severe degree.

Clinical Summary.-T. H., admitted on 18th October 1920, to Ward 37 of Glasgow Royal Infirmary, under Mr Pringle. Patient was taken ill on Tuesday, 12th October. He was troubled with pain in the abdomen which was not very severe. He became worse on 15th October, and the following day began to vomit. On admission on 18th October 1920, the abdomen was found to be rigid with tenderness in the right iliac region. Operation 18th October 1920. Pus found, appendix not removed. The following day patient began to vomit dark-brown material which gave blood reaction. This continued intermittently till he died on 20th October 1920.

Post-mortem 9971, 21st October 1920.-The body was that of a man of average build and stature. The skin had a yellowish tint. There was an operation wound in the appendix region with gauze packing. 
THorax.-There were old adhesions over both lungs and some hypostatic congestion and cedema.

Heart.-The left ventricle was hypertrophied. There was some sclerosis of the coronary arteries and old endocarditis of the aortic and mitral valve.

ABDOMEN.-The appendix was gangrenous and much thickened and lay behind the caecum. Pus was found in the region of the appendix, under the diaphragm on the left side and in the lesser sac of the omentum.

Stomach and Esophagus (Plate XXV.).-Externally the cesophagus appeared to be normal, but slightly thicker than usual. There were submucous hæmorrhages extending half way up. They were of a brownish-black colour. They ceased abruptly at the cardiac ring. At the upper end they became fewer and more scattered. No breaking down or ulceration could be recognised with the naked eye. On the posterior wall of the stomach towards the lesser curvature there was an area of congestion with submucous hæmorrhages of bright red colour which contrasted strongly with the dark colour of the hæmorrhages in the cesophagus. The stomach wall was soft, and at the cardiac end there was an appearance suggestive of gas under the mucous membrane, but there were no areas of post-mortem digestion or erosions, and no definite softening could be made out on comparison of the fundus and adjacent parts. There was nothing else of note except cloudy swelling of liver and kidneys.

Microscopic Examination.-Sections were prepared at two levels transversely and from a longitudinal strip which traversed the lower part of the cesophagus and adjacent area of the stomach.

In the transverse sections, it was found that there was severe damage to the mucous membrane. The epithelium had completely disappeared and the superficial tissues stained diffusely, the nuclear staining being totally lost or very greatly impaired. This condition extended in places into the muscularis mucosæ. The submucosa was swollen and glassy, and crowded with polymorphonuclear leucocytes. The hæmorrhages were marked by the presence of large quantities of dark-brown granular pigment in the mucous membrane; this was also present but less abundant in the neighbouring tissues. The red corpuscles were not recognisable in the hæmorrhages. The mucous membrane was extremely cellular. The character of the cells was obscured by degenerative changes, but polymorphonuclear lencocytes were very numerous.

The longitudinal section gave very important results. The gastric mucous membrane showed fairly marked digestion. The limits of the two types of mucous membrane could not be made out clearly, but in the gastric mucosa at a little distance from the osophagus, there was no reaction. In the oesophageal part of the section, the condition of the mucosa was very similar to that seen in the transverse sections but rather more advanced, and a most striking reaction was found in the connective tissues external to the outer muscular coat of the csophagus, where there was intense cedema and in places deposition of fibrin and rich leucocytic infiltration. This condition stopped at the level of the diaphragm, which was shown by the presence of a small group of voluntary muscular fibres. It is, therefore, quite clear that there had been considerable vital reaction in the mucous membrane and other tissues of the osophagus, whereas the stomach showed only post-mortem changes.

\section{TYPE II.-More Advanced Variety.}

Case 1.-Gall-stones, pancreatitis, excision of gall-bladder, hæmatemesis, digestion of cesophagus. Severe but not perforated. (Fig. 443, loc. cit.)

M. B., female, aged 24, was sent into the Royal Infirmary, Glasgow, under the care of Mr Pringle, on 14th January 1914, as an urgent case, with the diagnosis of perforation of a gastric ulcer. It was stated that she had been in good health up to fourteen days prior to admission. At that time she was seized suddenly

JOURN. OF PATH. - voL. XXIV. 
with severe epigastric pain, which was associated with vomiting. She remained in bed for five days, then resumed work, feeling well until the day of admission at 10 A.M., when she experienced a severe sharp pain in the epigastric region. She vomited on two or three occasions some greenish material before she came into hospital.

Condition on Admission.-The patient was very ill, the abdomen board-like and very tender. An immediate operation was carried out. The peritoneal cavity contained some brown turbid fluid. The omenta and mesenteries showed evidence of fat necrosis. The gall-bladder and common duct were packed with calculi. The pancreas felt extremely hard and had a deep yellow colour. The gastrohepatic omentum was much thickened and very œedematous. The gallbladder was excised, the common duct opened, a number of stones removed, and a drain tube sutured in. The pancreas was incised freely, a quantity of dirty brown fluid escaping from the incision and cut surfaces, but the wound made in it bled freely. 'l'his wound was packed.

After operation the patient vomited continuously small quantities of almost black fluid which gave a blood reaction, and she complained of a pain behind the sternum. Just before death, which took place thirty-eight hours after admission, the vomited material was bright red blood.

Post-mortem Report (No. 7606), 17th January 1914. - The body was that of a young woman, well built and well nourished, but decidedly anæmic. Midabdominal operation wound and small drainage wound above the pubis. No jaundice.

Thorax.-The heart and the aorta presented healthy characters. The lungs showed marked fine emphysema. The lower lobes of both showed an unusual degree of hypostatic congestion. There were no adhesions, and they stripped out quite easily, and no evidence of recent pleurisy could be made out, but it was only looked for after the recognition of the condition of the cesophagus.

Abdomen.-The liver showed advanced cloudy swelling and fatty change, boing of a pale yellow colour with little of the usual yellow markings. The spleen was normal. The kidneys showed advanced cloudy swelling. There were numerous patches of fat necrosis scattered about the pancreas, and near the tail there was a breaking down cavity with black necrotic appearance around the white necrosed fat. The pancreas was firm and of fairly normal colour. The duct was considerably wider than normal. The gall-bladder had been excised. The common bile-duct was much dilated and contained one facetted gall-stone, and the end of a drainage tube lay in it. The stomach was healthy in appearance. There was one small area of superficial hæmorrhage, but no post-mortem digestion. There was ulceration of the œesophagus of an irregular, slightly ragged type just above the cardiac ring, and there were many streaks of hxmorrhage in the mucous membrane running up to about the junction of the csophagus and pharynx. In colour these were dull brown, as if not absolutely recent. The tissues surrounding the lower part of the oesophagus seemed gelatinous, and were of a dark slate colour as if from the presence of altered blood (Fig. 443 in Journal of Surgery, loc. cit.).

Microscopic Examination.-Section of cardiac region of stomach and osophagus. The gastric mucous membrane showed much loss of nuclear staining, indicating that there was post-mortem digestion microscopically although in a very early stage. There were no signs of reaction.

CEsophagus.--Where the gastric mucosa became thin the digestion became more marked, and immediately above the ring (shown by the presence of diaphragmatic muscle in the section) the digestion and destruction began. The muscularis mucosie was completely destroyed, and the submucosa broken down almost to the muscular coat. There was very little nuclear staining in the inner muscular coat but there was no breaking down. There was rcaction in and 
around some of the vessels of the areolar tissue outside the muscle. In the muscle were a number of gas cavities and the cligested shreds and connective tissue planes right through were full of bacteria. The bacteria extended into the gastric submucosa along the spaces of the tissuc, but there was neither reaction nor swelling of this layer. On the other hand, just above the broken end of the muscularis mucosæe there was a vessel in a shred of surviving submucosa in and around which there were some leucocytes. Higher up more of the submucous connective tissue, which was swollen and digested to unequal depths, had survived, and, where the section entered the lower end of the big streak of hæmorrhage there were quantities of brown granules. Here, too, more of the submucosa had survived and leucocytes were abundant in it. The good nuclear staining of the leucocytes! contrasted strongly with the loss of nuclear staining in the original tissues. In the case of the muscular coat this degeneration extended on the average haif through the inner layer. The upper transverse section showed the characteristic ulcers thickly infiltrated with brown granules of pigment, and between the ulcers the surface of the mucosa was bare and sharply defined with loss of nuclear staining and on it were many bacteria. The epithelium in the latter areas had apparently been shed only after death. The submucosa showed the usual swollen glassy condition with leucocytic infiltration. This œsophagus showed a lesion somewhat more severe than that in the preceding case. There was also a good deal of digestion or maceration post mortem. The absence of general blackening was thought to be due to removal of the sloughs and solution of the pigment by this maceration.

TXPE III.-Advanced. (Fig. 444 in Journal of Surgery, and Plate XXII., Fig. 1.)

Case 4.-Appendicitis with abscess and peritonitis. Hæmatemesis before operation. Advanced digestion of cesophagus. Perforation. Fibrinous pleurisy.

L. M'C., female, aged 16, was admitted to Glasgow Royal Infirmary on 2nd October 1918, under the care of Mr Pringle, as a case of acute appendicitis. The patient was extremely ill, pulse 132 , temperature $1042^{\circ}$, respirations 44 . The patient, who had previously been in good health, was seized with severe pain in the region of the umbilicus on $29 \mathrm{th}$ September. She vomited soon after, and this recurred several times. The abdomen was tense, rigid, and tender all over. Dullness was present in both flanks. Nothing unusual was made out by rectal examination. Lungs clear. The patient vomited twice after coming into the ward, and before her operation, which was done as soon as possible, about five ounces each time of a dark-brown, almost reddish, fluid. A small abscess was found at the appendix, and there was a generalised purulent peritonitis. The appendix was not removed. The abscess was drained. The patient died at 6 A.M. the following morning, twelve hours after admission. She vomited twice after the operation, each time bringing up a mouthful or two of the same dark-brown fluid that had been ejected before the operation.

Post-mortem Report (No. 9244), 4th October 1918.-The body was that of a well-built, well-nourished girl. There was in very marked degree the dusky complexion which is seen in septic cases.

Thorax.-The heart showed some cloudy swelling. The lungs from the front were seen to be congested, but appeared generally normal. The left lung was found to be lightly adherent to the diaphragm, and on cutting the root and lifting up the lung a quantity of black fluid was seen coming from the cesophagus, and the tissues between that structure and the lung were pulpy and of dirty black colour. There was no definite digestion of the surface of the lung, but on the diaphragmatic surface there were some thin flakes of fibrin, and there were some sub-pleural hremorrhages. The condition of the right side was similar to that on the left, there being a thin fibrinous exudate between the lung and the diaphragm, and also between the back of the lower lobe and the posterior wall 
of the thorax. There were numerous subpleural hæmorrhages in the inner and diaphragmatic aspects of the lung. The cesophagus appeared as a black, ragged band; and at three points, respectively about 2 ins. and 3 ins. above the diaphragm, it was perforated, and black fluid was escaping. The oesophagus, lower part of trachea, and stomach were removed en masse. The digested condition of the csophagus stopped abruptly at the upper surface of the diaphragm. There was no pus above the diaphragm, and it appeared highly improbable that the fibrinous exudate in the pleural sacs was due to extension of the suppuration from the abdomen, the substance of the diaphragm and the connective tissue below it appearing quite normal.

Abdomen.-There was a general purulent peritonitis, the cause of which was gangrene of the appendix. The liver and kidneys showed marked cloudy swelling. The spleen was slightly enlarged with soft full pulp. The stomach, which was examined along with the cesophagus, contained a small quantity of slaty-grey fluid quite different in character from the black fluid which was present in the cesophagus. There was very slight post-mortem digestion of the fundus of the stomach, with minute extravasation of blood into the mucous membrane; otherwise it presented normal characters.

Microscopic Examination.-Sections were prepared from part of the left lung, where the surface was markedly digested, having been in contact with the csophagus without interposition of the pleural membrane. The areolar tissue was necrotic, and showed no reaction. The surface of the lung in parts was also necrotic. This condition involved a superficial layer of at most two to three alveoli. Beneath this the alveoli were occupied by blood. Some of the necrotic alveoli seemed also to have contained blood. Deeper still the condition passed into œdema of the lung, with more or less of hæmorrhage. There was very little sign of reaction, but polymorphonuclear leucocytes were recognised in places in greater number than would be accounted for by the presence of blood. There was marked congestion.

A section was also prepared from the surface of the right lung where there was a fibrinous exudate. There was a good deal of degenerative change in the exudate, but its character was quite distinct. The cells were to a considerable extent mononuclear, with a fair number of polymorphonuclear leucocytes, and there was swelling and proliferation of the endothelium of the pleura. The lung showed a condition similar to that already described. There could be no question as to the presence of vital reaction.

The condition of the cesophagus just above the cardiac ring has already been described (see p. 402). The mucous membrane was digested away down to the circular muscle and signs of reaction were found only at a few points. Higher up the black sloughs were in place and consisted of swollen more or less necrotic remains of tissue loaded with pigment and bacteria. There was considerable leucocytic infiltration. In the upper parts the condition became similar to that in Case 17 (Plate XXV., and Plate XXII., Figs. 3 and 4).

Case 2 (7921) provided a surprise. A youth, aged 18, was crushed, and at operation there was found to be an extensive rupture of the liver. The hæmorrhage was arrested and the patient rallied wonderfully, but died suddenly some hours after the operation. Pulmonary embolism was suspected. The patient vomited on one occasion only, and that shortly before death, a small quantity of dark coffee-ground material being ejected. There was advanced digestion of the lower parts of the csophagus with black staining of the damaged tissue, and the blackening of the mucous membrane extended up to the pharynx. 
It was of a diffuse type. The stomach presented healthy characters. Microscopically also it was remarkably free from post-mortem change.

Sections were made at several points from the lower end up to the pharynx. There was congestion of the blood-vessels and much blood pigmentation, but no cellular reaction could be made out. Microscopic appearances were, therefore, those of post-mortem digestion unless the congestion were interpreted as a vital phenomenon. Clinically, however, the case was of vital origin, coffee-ground material having been vomited and no source of hæmorrhage except the cosophagus could be discovered. Sub-pleural hæmorrhages were present about the margin of the digested areas of the lungs, and from the presence of these, the appearance of the osophagus and the history, we concluded that this was an example of ante-mortem digestion. We are still of the opinion that it was of this nature, but that the extreme exhaustion of the patient led to rapid collapse when the digestion of the osophagus began, and that there was neither energy nor time for cellular reaction to take place.

In Case 18 (Appendicitis), the cesophagus was very similar, and the clinical history resembled that of Case 2 inasmuch as the patient became extremely weak from repeated hæmorrhages from the bowel, which were due to an unsuspected duodenal ulcer. There was no hæematemesis. The end came suddenly. In this case considerable reaction was found in the csophagus.

In our opinion all examples of advanced digestion of the cesophagus, in which the stomach shows relatively slight or no digestion, should be regarded as vital in nature.

\section{Indications of Healing Processes in Ulceration of the QEsophagus.}

It seems probable that in some of the cases recorded in 1919, healing might have taken place had the patient lived. A far worse local condition of the csophagus must have been induced in many instances where caustic fluids have been swallowed and in which recovery took place. It was, therefore, with interest that the specimen from which Plate XXV., Fig. 16, was drawn was investigated. The mucous membrane was divided up into rounded islets by narrow furrows floored with reddish tissue which looked like ulcers. Microscopic examination proved these to be ulcers of a somewhat indolent type but apparently healing. It is not certain that this case belonged to the same category as the acute digestions of the osophagus. The primary disease was cancer of the pylorus. There had been much vomiting of coffee-ground material during the last ten days.

In Case 12 (Puerperal eclampsia-five days. Hæmatemesis: date not recorded) of the series, however, distinct evidence of healing was obtained (Plate XXIV., Figs. 10 and 11). The injury to the œsophagus 
was of a very slight degree, and in large parts of the sections the epithelium was in existence. It was, however, irregular and had hardly any cornified layer, and karyokinetic figures were numerous. The ulcerated parts of the mucous membrane, where free from post-mortem degeneration, showed that reaction had affected the connective tissue elements and vessels to a considerable degree.

Case 14 was one of fracture of femur, and abdominal section was performed on account of urgent symptoms suggestive of duodenal ulcer eleven days later. Vomiting of dark material occurred forty-two hours ante mortem, and ceased after operation twenty-eight hours ante mortem.

Slight ulceration of the csophagus of the digestive type was found (Plate XXIII., Figs. 5 to 8), but no ulceration of stomach or duodenum. In this case also there were indications of reaction of longer standing than in the more severe cases. The cause of death appeared to be broncho-pneumonia commencing in an exhausted subject.

\section{SUmmaRY AND CONCLUSIONS.}

Post-operative vomiting of black material or hæmatemesis is a symptom of great importance to the practical surgeon. In some cases the cause of this symptom appears to be digestion of the osophagus. Vomiting of black material or blood in the course of non-surgical diseases may also be attributable to the same cause. Such cases are all of a severe infective or toxic nature. In all, sixteen fatal cases have been observed by us in the last seven years. The characteristic vomiting has been observed most commonly from thirty-six to twenty-four hours before death.

The condition of the cesophagus may vary in different cases from superficial orosion of the mucous membrane to deep ulceration and perforation or extensive destruction of the tube and digestion of adjacent structiures. Hæmorrhages are always present in the wall of the csophagus and may be present also in the lungs and pleuræ. In contrast with the state of the oesophagus there is little or no digestion of the stomach, and the cardiac orifice is found closed.

Microscopically the condition is a severe ulceration accompanied by more or less necrosis and solution of tissue and acute inflammatory reaction. Healing reaction has been observed.

Conclusions.-Digestion of the cesophagus, therefore, may occur during life, and as a result blood or black fluid may be vomited. This is not an agonal condition but one the nature of which can be diagnosed during life and which might be amenable to treatment. It is not extremely rare. In all probability these cases of digestion during life have commonly been regarded as merely post-mortem digestion and their significance in relation to hæmatemesis has been overlooked. 


\section{REFERENCES.}

1. Kaufmann . . . . . Specielle Pathologische Anatomie, Berlin, 1909, 5th Ed., p. 388.

2. Pringle, J. Hogarth, and Brit. Journ. of Surgery, 1919, vol. vi. No. 24, Teacher, JoHN H. p. 523.

\section{DESCRIPTION OF PLATES.}

\section{Plate XXII.}

FIG. 1.-Longitudinal section of the lower end of the osophagus in Type III. (Case 4), showing the edge of the gastric mucous membrane ending abruptly at the zone of acute ulceration. The cesophageal mucons membrane has been digested away and the submucous tissue is exposed and the vessels are thrombosed. At the right of the section the digestion extends down to the inner muscular coat. ( $\times 20$.)

FIG. 2.-Section through the mucous membrane and submucous coat from an advanced variety of Type II. The tissue was black and considerably digested. In the upper part of the specimen the larger dark bodies represent the remains of the muscularis mucosæ. There is considerable leucocytic infiltration. At the lower part of the figure is seen a vein containing a thrombus. The wall on the superficial side is in a state of coagulation necrosis with leucocytic infiltration. The deep side is practically normal. ( $\times$ 100.) (Case 16.)

FIG. 3.-Transverse section of the oesophagus in Type II. (Case 17, Figs. 15, 16) through the hæmorrhages. The mucous and submucous coats are greatly thickened; the surface eroded, the muscularis mucosæ hardly distinguishable through being more or less necrotic, and the submucous areolar tissue thickened, glassy, and infiltrated with leucocytes. A great deal of the dark staining of the mucosa is due to the presence of pigment representing the hæmorrhage. ( $\times 20$.)

FIG. 4.-Portion of the same, showing the mucous membrane thickly infiltrated with leucocytes and pigment; also small thrombosed vessels. $(\times 100$.

\section{Plate XXIII.}

FIG. 5.-Longitudinal section of the esophagus from Type I. (Case 14). Slight. The epithelium has disappeared. The mucous coat and the muscularis mucosæ are somewhat thickened and infiltrated with leucocytes. The dark patches indicate lymphoid tissue. The submucous connective tissue is swollen and glassy. Contrast Fig. 12. $(\times 20$.

Fig. 6.-Portion of the same, showing the surface at one of the lymphoid follicles, which is thickly infiltrated with leucocytes. The muscularis mucosæ shows numerous leucocytes and pigment, and in the submucosa the fibres are swollen and glassy and there are some leucocytes. ( $\times 100$.

FIG. 7.-Part of the same, showing the polymorphonuclear character of the leucocytes. $(\times 200$.)

Fig. 8.-A small acute ulcer from the upper part of the same specimen, showing the breach in the epithelium and the acute infammatory infiltration of the mucous membrane. The surface of the mucosa also shows early digestion; the fibres are swollen and the nuclei of the tissue cells have lost their capacity to take the stain. $(\times 100$. $)$

FIG. 9.-The margin of a healing ulcer of the csophagus (Plate XXV., Fig. 16), showing the edge of the epithelium with migrating leucocytes and the granulation tissue floor of the ulcer. Note the comparative absence of leucocytes from the blood-ressels showing that the acute stage is past. $(\times 100$. 


\section{Plate XXIV.}

FIG. 10.- Section of the mucous membrane from Type I. (Case 12) where the condition is passing from the stage of acute reaction and healing is commencing. The epithelium is thin and there is absence of the horny layer. Karyokinetic figures are present. A small blood-vessel is seen containing numerous leucocytes and there is evidence of reaction on the part of the connective tissue elements. Compare Fig. 11. ( $\times$ 100.)

Fig. 11. - Part of the same $\times 200$. Note the karyokinetic figure beside the small vessel containing many leucocytes.

Fig. 12.-Transverse section of an œesophagus, showing post-mortem desquamation of the epithelium. Note the distinctness of the fibres of the muscularis mucosæ and submucous tissue. Contrast Figs. 3 and 5. $(\times 20$.

Frg. 13.-Portion of the same, showing the edge of the desquamated epithelium which is otherwise strictly normal. Note the absence of acute reaction in the tissue and vessels of the submucosa. $(\times 100$.

FIG. 14.-Longitudinal section from the same case as Figs. 5, 6, 7, and 9, showing inflamed mucosa which has suffered from continuance of digestion. The nuclear staining is lost. There is a certain amount of pigmentation. $(\times 100$.)

\section{Plate XXV.}

FIG. 15.-Naked-eye appearances of csophagus in Case 9971, p. 404.

FIG. 16.-Healing ulceration of cesophagus, p. 409. 


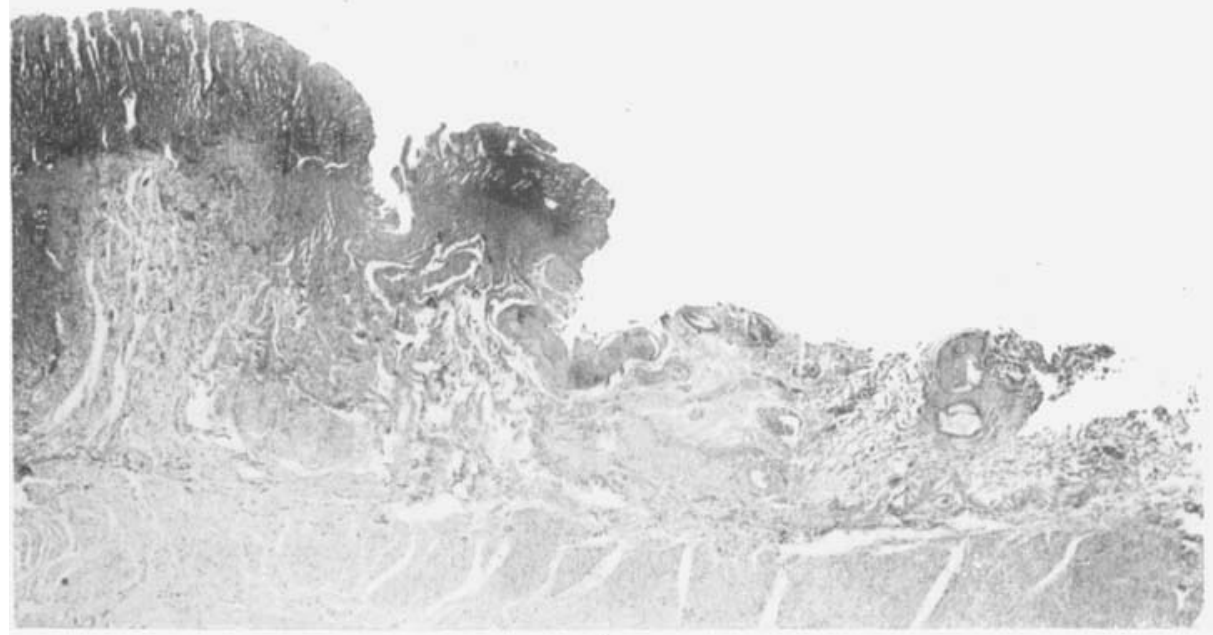

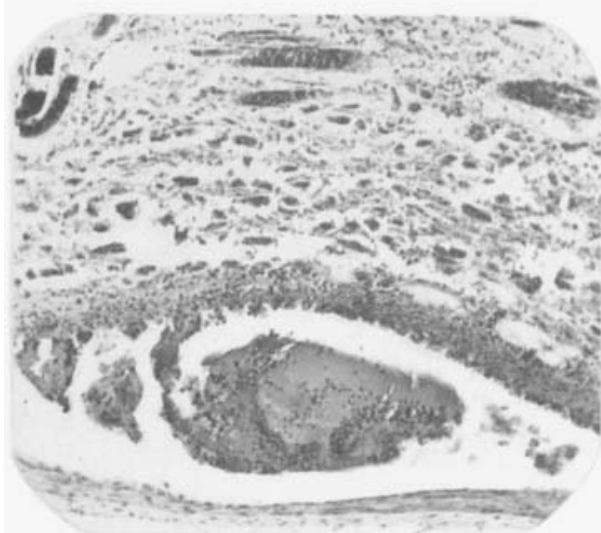

2

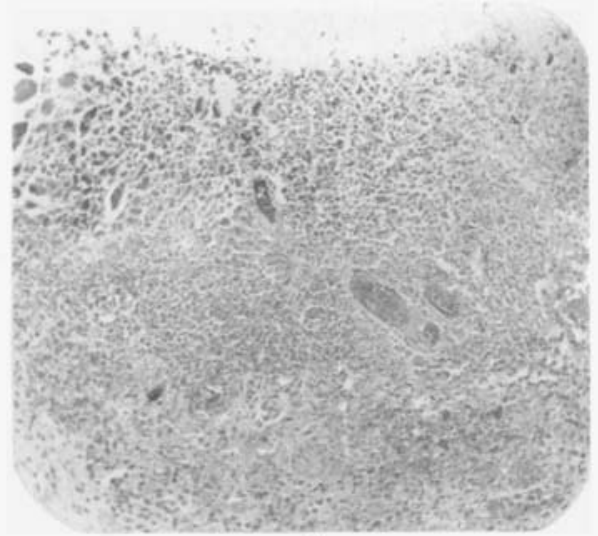

4

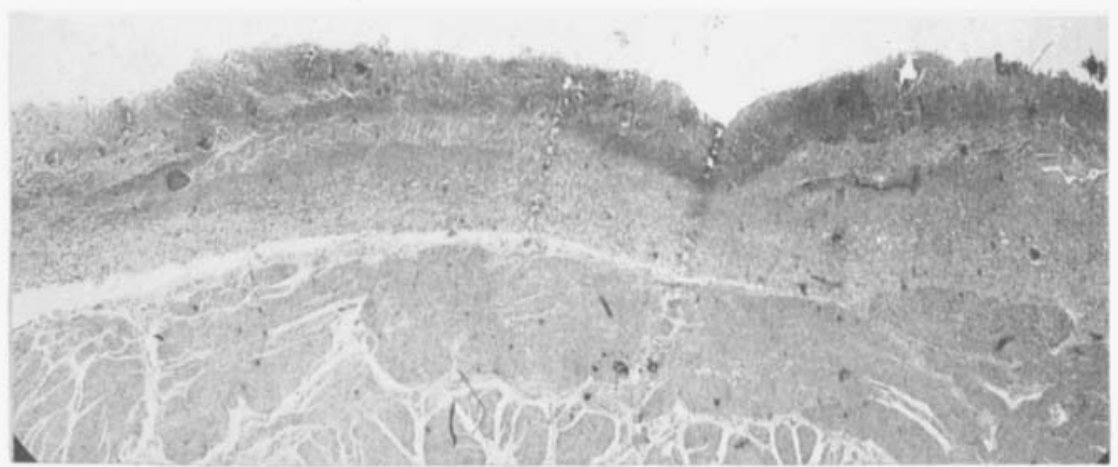



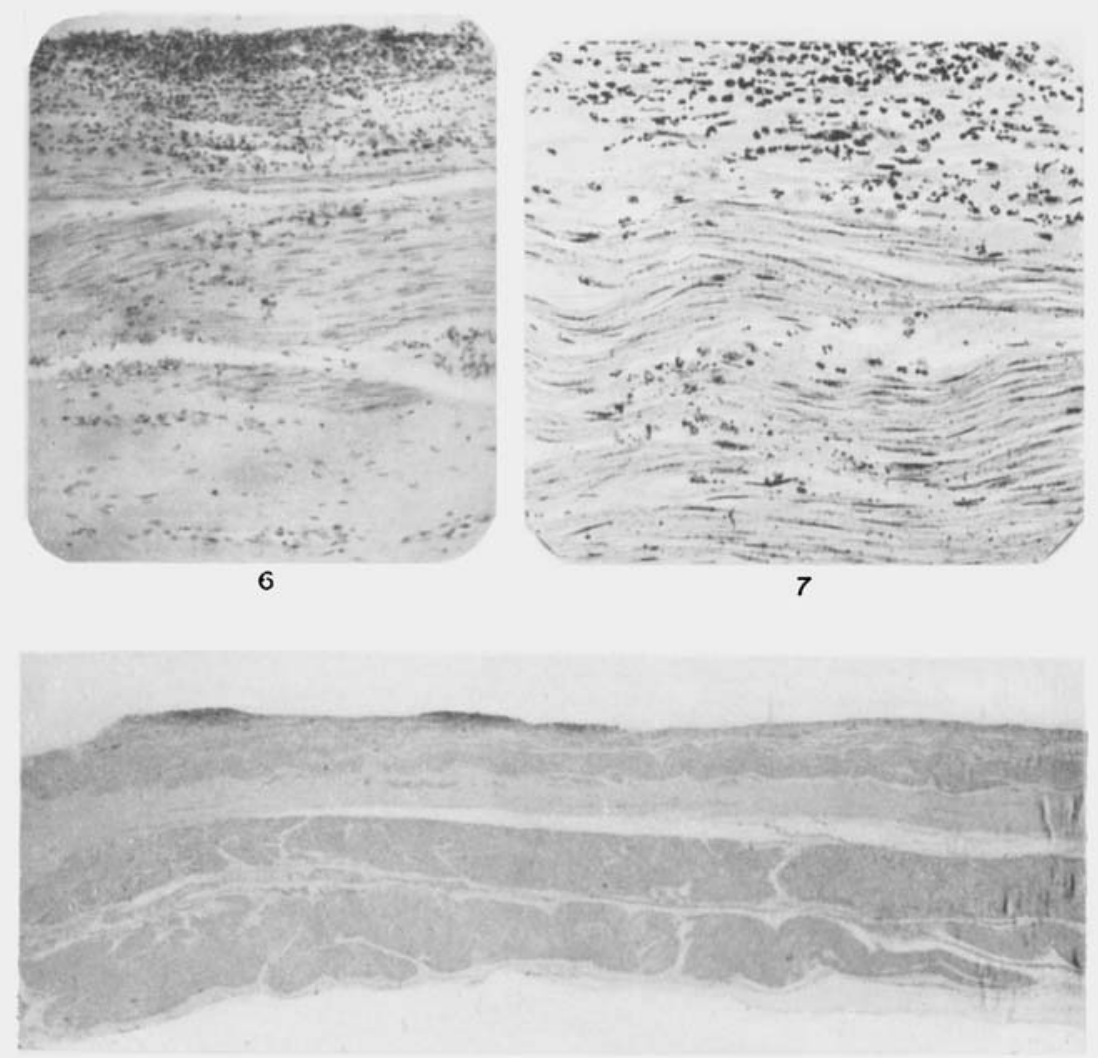

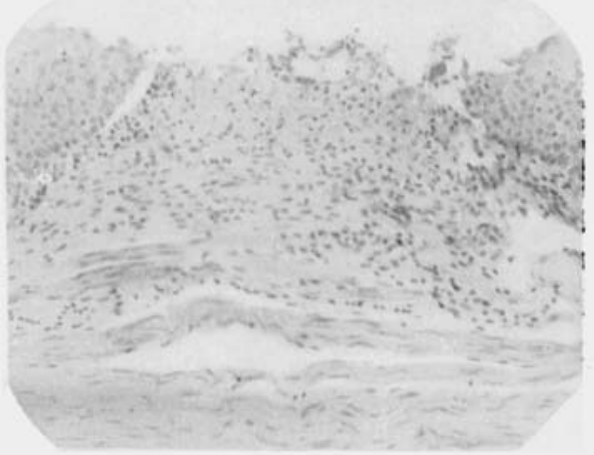

9

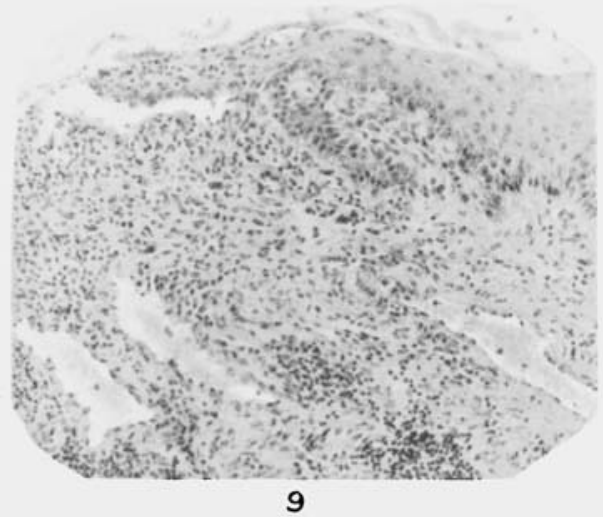

9 


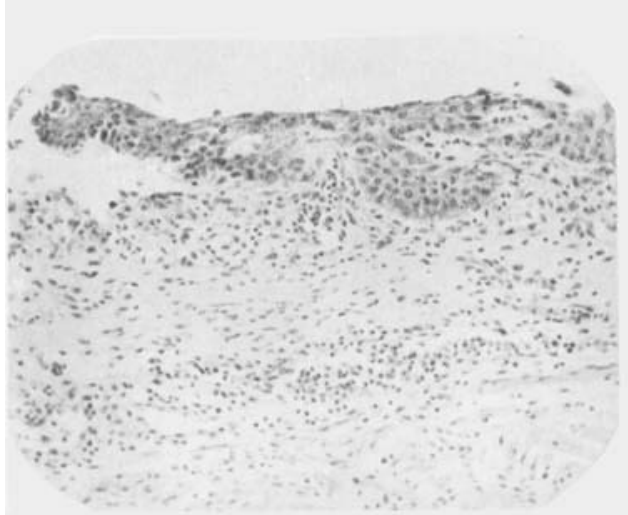

10
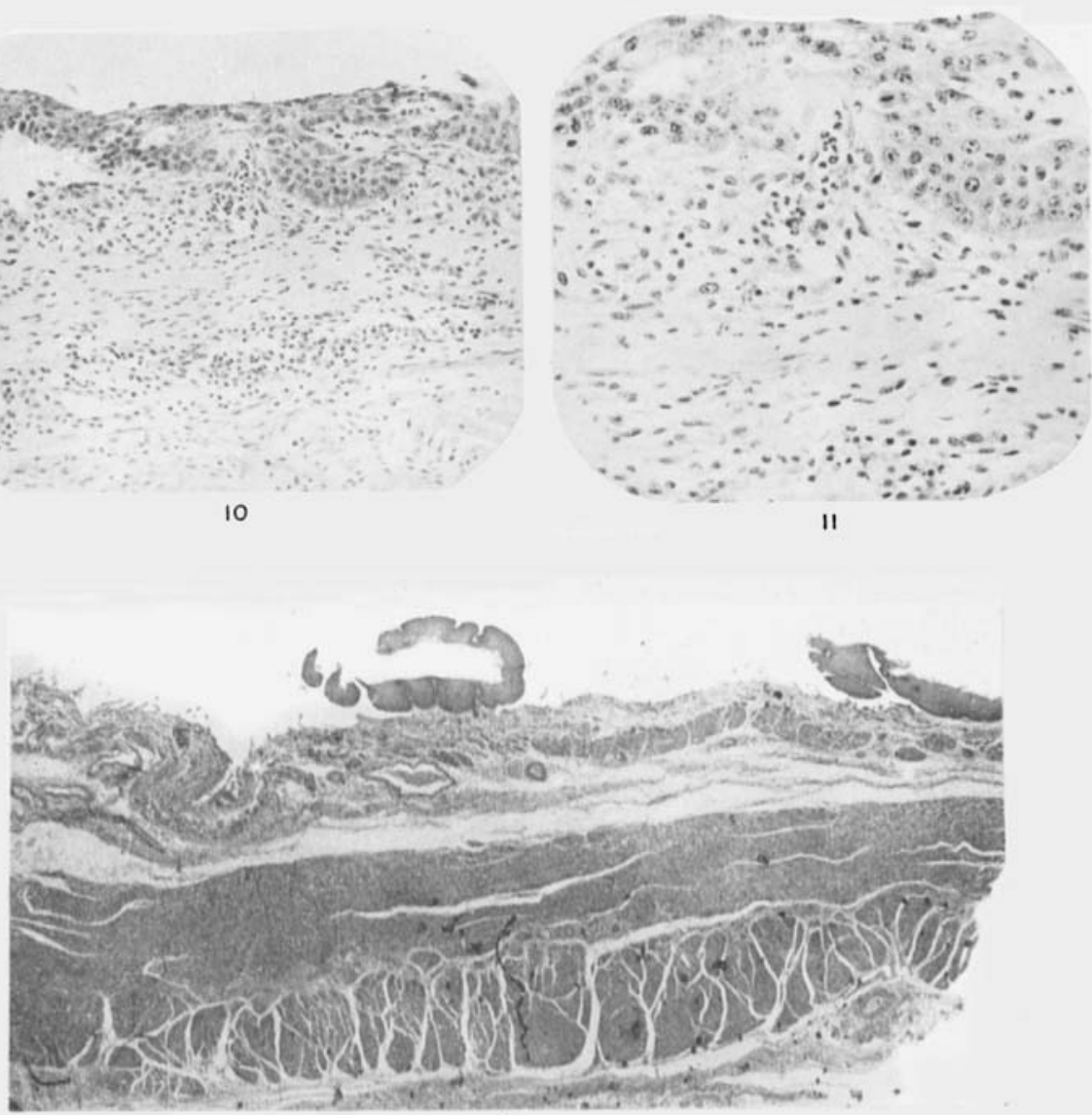

12
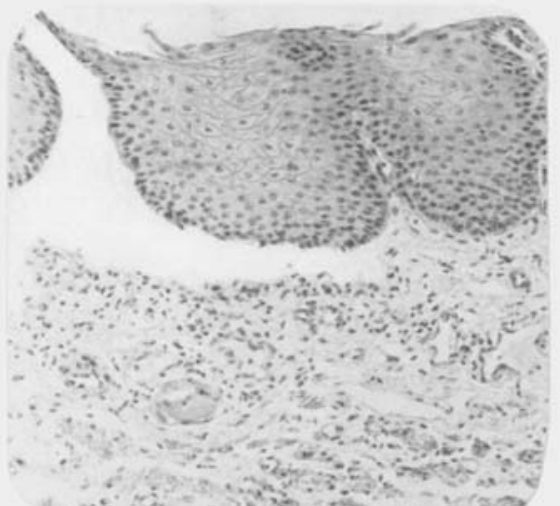

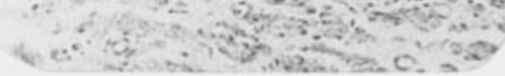

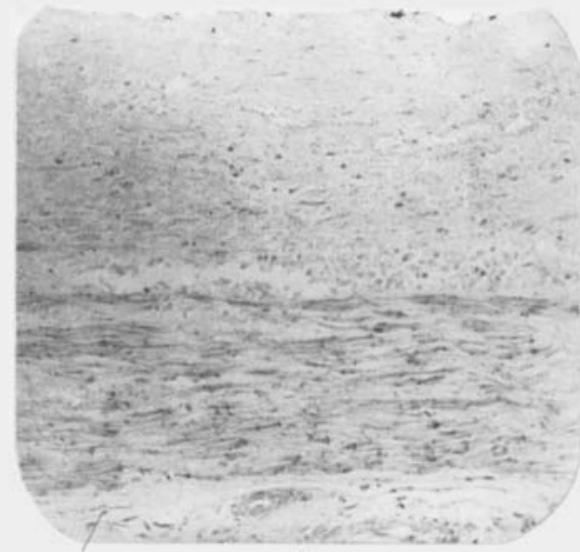

14 
JOURNAL OF PATHOLOGY.--VOL. XXIV.
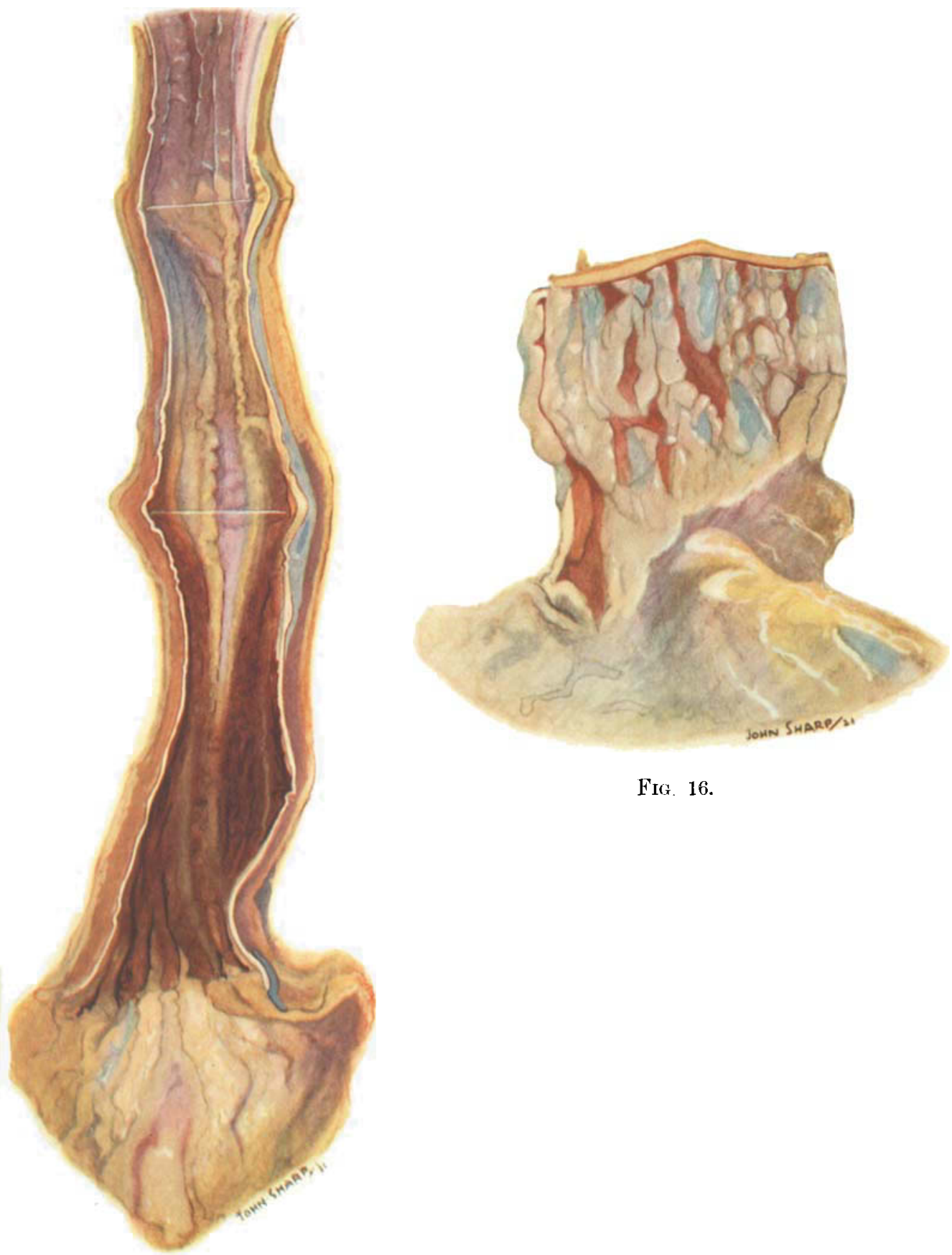

FIG 16.

Fig. 15. 